\title{
Does Political Knowledge Increase Turnout? Evidence from the 1997 British General Election
}

\author{
Valentino Larcinese ${ }^{* *}$ \\ Department of Government and STICERD \\ London School of Economics and Political Science
}

PEPP/1

February 2005

Political Economy and Public Policy Series

The Suntory Centre

Suntory and Toyota International Centres for

Economics and Related Disciplines

London School of Economics and Political Science

Houghton Street

London WC2A 2AE

Tel: (020) 79556674

\footnotetext{
* Address for correspondence: London School of Economics, Department of Government, Houghton Street, London, WC2A 2AE, United Kingdom, Tel. +44 (0) 207955 6692. Fax: +44 (0) 207955 6352. Email: V.Larcinese@1se.ac.uk.

* Acknowledgements: I am very grateful to Tim Besley for helpful discussions during all stages of this project and for comments and suggestions on a number of previous versions of this paper. I also wish to thank Oriana Bandiera, Richard Blundell, Harold Clarke, Keith Dowding, Guillaume Frechette, Cesar Martinelli, Maria Pia Monteduro, Imran Rasul, Leo Rizzo, Cristiana Vitale and Donald Wittman as well as participants in a number of meetings and seminars for their useful comments and suggestions. I remain the sole responsible for limits and errors of this work. Financial support from the European Commission under the TMR Scheme (Marie Curie Fellowship) and from ESRC is gratefully acknowledged.
} 


\begin{abstract}
A number of recent formal models predict a positive effect of political knowledge on turnout. Both information acquisition and turnout, however, are likely to be determined by a similar set of variables, rendering hard the identification of a causal link in empirical investigations. Available empirical regularities should therefore be interpreted as mere correlations. I address this problem by using an instrumental variables approach, where the instruments are represented by various proxies of information supply on mass media. Using survey data from the 1997 British General Election Study, I show that political knowledge has a sizeable influence on the probability of voting and that mass media play an important role in influencing political participation.
\end{abstract}

Keywords: voting, information, mass media, political participation

JEL: D72, D83

(C) The author. All rights reserved. Short sections of text, not to exceed two paragraphs, may be quoted without explicit permission provided that full credit, including $\odot$ notice, is given to the source 


\section{Introduction}

In an idealized vision of democracy, public decisions are based on the preferences and the opinions of all the members of a polity. It is therefore common in the public debate to regard the extent of electoral participation as a measure of the quality of democratic governance. Low turnout is sometimes seen as a symptom of little attachment to public affairs and even to democracy itself and is therefore associated with the danger of a self-referential political class. On the other hand, however, high participation is not compelling evidence of healthy democratic governance, and many de facto dictatorial systems show extremely high turnout rates. At the same time, abstention could be interpreted as satisfaction rather than disinterest.

Understanding the determinants of turnout is central to this debate and can provide a substantial insight on the quality of democratic governance and the possible steps to improve it. A central question is whether more and better political information can increase voters' participation. Uninformed participation is, after all, not necessarily better than no participation at all.

Starting with the study of Wolfinger and Rosenstone (1980), a vast empirical literature consistently finds positive correlations between turnout and individual characteristics such as income and education. This implies that "low voter turnout means unequal and socioeconomically biased turnout" (Lijphart, 1997), and therefore participation levels can influence public policy. Evidence in support of this has been found by numerous scholars who have shown, for example, that social spending is positively affected by aggregate turnout (Peterson and Rom,1989; Hicks and Swank, 1992; Levitt and Snyder, 1995; Lindert, 1996; Stromberg, 2004), by lower-class mobilization (Hill and Leighley, 1992, and Hill, Leighley and HintonAndersson, 1995), and by the extension of the voting franchise ${ }^{1}$ (Husted and Kenny, 1997).

Recent formal models link information to voter participation (Matsusaka, 1995; Feddersen and Pesendorfer, 1996; Ghirardato and Katz, 2002). There is, however, little empirical evidence in support of these models. Available evidence that education affects turnout (Milligan et al., 2003) provide only indirect support. Some studies are based on subjective assessments of knowledge (Sanders, 2001; Lassen, 2005). Direct measures of political knowledge show that better informed citizens are more likely to vote (Delli Carpini and Keeter, 1996; Wattenberg et. al., 2000), but this relationship has to be interpreted with caution. Political knowledge is not

\footnotetext{
${ }^{1}$ Besley and Case (2003), however, find no evidence of an impact of turnout on the composition of US state legislatures.
} 
an exogenous variable: the same motivation that leads to participation is likely to drive information acquisition. Thus, the link between information and turnout could be a spurious correlation driven by unobserved voters' heterogeneity.

In this paper I address this issue by providing an instrumental variable estimation of the effect of information on turnout using data from the 1997 general election in the United Kingdom. I conclude that, at least in the context analysed here, political knowledge has a sizeable and statistically significant impact on the British citizens' likelihood of voting. The instruments consist of proxies for the supply of news on the British media: thus, I also conclude that mass media can have an important indirect (i.e. via political knowledge) impact on participation.

\section{Information and turnout}

Politicians appear to struggle for the attention of mass media. Campaign strategies tend to be heavily conditioned by access to media and spin doctors are increasingly influential. Political advertising and access to television are regulated in many democratic countries during electoral campaigns. Either explicitly or implicitly, these phenomena must be based on the presumption that information matters for voting behaviour.

However, various arguments in support of the idea that information is "behaviour irrelevant" have been recently elaborated by Popkin (1991), Wittman (1995), and Lupia and McCubbins (1998). Their main argument is that voters use heuristics and manage to behave as if they were informed ${ }^{2}$. Also, using spatial models of elections, a number of papers show that it is possible for imperfectly informed voters to emulate the behaviour of the better informed ones when they receive a credible signal from a source whose preferences are known (McKelvey and Ordeshook, 1984; Calvert,1985; Sobel, 1985; Grofman \& Norrander, 1990; Lupia, 1992). If party platforms tend to be consistently tied to the interests of specific socioeconomic groups, then party identification or public endorsements can provide a simple and effective way to vote instrumentally. Bartels (1996), using the National Election Study surveys conducted for six US presidential elections, finds instead that uninformed voters "do significantly better than they would by chance, but sig-

\footnotetext{
${ }^{2}$ Sniderman, Brody, and Tetlock (1991) define heuristics as " judgmental shortcuts, efficient ways to organize and simplify political choices, efficient in the double sense of requiring relatively little information to execute, yet yielding dependable answers even to complex problems of choice" (p.19). Evidence on the use of heuristics is provided, among others, in McKelvey and Ordeshook (1984), Brady and Sniderman (1985), and Lupia (1994).
} 
nificantly less than they would with complete information, despite the availability of cues and shortcuts". For what concerns turnout, if information does not increase the utility of casting a vote then it should also not affect participation. This conclusion, however, is not supported by empirical research. Palfrey and Poole (1987), for example, use ICPSR survey data from the 1980 presidential election in the US to show that information is significantly related to both political extremism and turnout.

A number of formal models on information aggregation put forward the idea that, in spite of its influencing individual voting behaviour, political information can be "outcome irrelevant". In Feddersen and Pesendorfer (1996 and 1999), noninformed voters have an incentive to delegate their choice to the better informed to increase the chances of an informed aggregate decision. Delegation takes place via abstention, which increases the probability of any informed voter being pivotal. This argument relies on the assumption that non-partizan voters share the same objective function. Thus, in delegating their decision to other non-partizan voters, the uninformed do not incur the risk of leaving the decision to people with different tastes $^{3}$.

Matsusaka (1995), presents a decision-theoretic model of the impact of information on turnout based on the idea that better informed choices provide more utility to Bayesian voters. Ghirardato and Katz (2002) show that non-Bayesian "ambiguity-averse" voters are even more prone to abstain than Bayesian voters when they receive poor quality information.

It seems fair to say that the evidence in support of such models is still limited: in particular, despite a vast body of empirical research on the determinants of turnout, we are still far from knowing whether there is any causal link between political knowledge and participation. Education has often been found to have a high influence on turnout (Wolfinger and Rosenstone, 1980; Matsusaka and Palda, 1999; Milligan et al., 2003) ${ }^{4}$. It is possible to rationalize this empirical regularity on the ground that education reduces the costs of acquiring information. In empirical terms, however, education and information can be correlated for a number of other reasons, including the fact that formal education might increase socialization, sense of efficacy, and the identification with the general values of a society.

\footnotetext{
${ }^{3}$ Feddersen and Pesendorfer's argument fits in the tradition of the so-called "Condorcet-jury theorem" (Young, 1988, Austen-Smith, 1990, Austen-Smith and Banks, 1996), where the assumption of common objective functions is clearly less problematic than in political elections.

${ }^{4}$ In Britain, however, such influence has not been found to have high statistical significance (Denver, 2003).
} 
Sanders (2001) uses survey data from the 1996 US presidential election to show the importance of perceived uncertainty about candidates for turnout ${ }^{5}$. Delli Carpini and Keeter (1996) go one step further by using direct measures of political knowledge from the 1988 NES Survey and showing that these are good explanatory variables of turnout. Wattenberg et al. (2000) show that voters who are more informed about the US House are more likely to vote in the House elections. This is, however, still one step short of showing that information determines turnout, since political knowledge is an endogenous covariate.

To illustrate this endogeneity problem, suppose we want to estimate the effect of information on turnout and let us consider a simple model of instrumental voting. In the classical formulation of Riker and Ordeshook (1968), a citizen votes if

$$
P B+D>C
$$

where $P$ is the probability to cast a decisive vote, $B$ is the gain in policy benefit derived from the victory of the preferred candidate when compared with the alternatives, $D$ is the psychological benefit of voting and $C$ is the cost. Political information helps the citizens to form a more precise idea about $B^{6}$.

Assume now that there are only two candidates, that the policy space is unidimensional and that $B$ depends on the distance $\delta$ between the two proposed platforms. The optimal decision for the voter depends on the value of $\delta$. We can indicate with $W(\delta)$ the maximum value function derived from the maximization of $U(\delta)=P B(\delta)+D-C$ with respect to the voting decision. Now suppose that $\delta$ is unknown and has to be estimated. If $\widehat{\delta}$ is a more precise estimate than $\widetilde{\delta}$ of the true $\delta$, then we can say that the value of using $\widehat{\delta}$ instead of $\widetilde{\delta}$ is given by

$$
E_{\delta} W(\widehat{\delta} ; \delta)-E_{\delta} W(\widetilde{\delta} ; \delta)
$$

where $E_{\delta}$ represents the expected value operator. If the cost of passing from estimate $\widetilde{\delta}$ to estimate $\widehat{\delta}$ is $c$ (for example to acquire more observations), then such

\footnotetext{
${ }^{5}$ In a very different context, Coupe' and Noury (2004) show that, during a National Research Council investigation, US academics who declared themselves more familiar with specific doctorate programs were also more likely to express an evaluation on these programs.

${ }^{6}$ Other elements in (1) can be influenced by information: for example the perception of $P$ can be affected by the polls published during the electoral campaign. I focus on $B$, because it is the element that reflects the policy platforms and can, therefore, be related to political knowledge in a strict sense.
} 
acquisition will take place if and only if

$$
E_{\delta} W(\widehat{\delta} ; \delta)-E_{\delta} W(\widetilde{\delta} ; \delta)+b>c
$$

where, as in the voting equation (1), I add a personal benefit $b$ which represents the non-instrumental enjoyment of political information, orthogonal to political preferences. The problem in testing the effect of information on turnout arises as $D$ and $b$ are likely to be correlated, both being driven by some sense of civic duty or pure enjoyment of politics. Finding a positive relation between information and turnout could therefore just be the consequence of omitting relevant variables from the empirical analysis.

To identify the effect of information on turnout we need a theory of how political knowledge is formed. Following Luskin (1990), we can say that voters' learning of a particular subject depends on "the political information to which people are exposed, their ability to assimilate and organize such information, and their motivation to do so". Of these determinants, only the first appears to be genuinely exogenous and therefore capable of providing instrumental variables to identify information effects on turnout. Thus, in the turnout equation I instrument political knowledge by using various measures of the information supply to which voters have been exogenously exposed. As a by-product of this analysis we also get an insight on the determinants of the political knowledge of British voters and on the role of the media.

Two other papers provide empirical studies of the impact of information on turnout and take into account the endogeneity problem. Stromberg (2004) provides evidence of the impact of the diffusion of radio on the distribution of New Deal spending and finds that a part of this effect can be explained by the fact that radio fostered turnout: a $1 \%$ increase in the share of radio ownership in a county increased the turnout rate by $0.12 \%$. This is a very interesting finding but it is based on aggregate data and therefore it cannot demonstrate that it was increased political knowledge which determined increased turnout. Only the use of survey data can address this issue in a direct fashion. Lassen (2005) uses survey data from a referendum on decentralization held in the city of Copenhagen. Since four out of fifteen districts carried out a pilot project of decentralization before the referendum, the voters living in such districts are assumed to have exogenously been exposed to better information. Voters are assumed to be informed if they have an opinion on decentralization, not informed otherwise. Lassen finds that information has a 
sizeable and significant impact on turnout.

In Lassen (2005), turnout is self-reported, which probably overestimates the propensity to vote. For this reason I will use instead verified turnout data. Even more importantly, Lassen uses a measure of political knowledge that, apart from being extremely coarse, does not allow the observer to distinguish knowledge from pure beliefs (which are not necessarily based on information). In terms of the Feddersen and Pesendorfer model, for example, one would like to be able to distinguish not only the informed voters from the uninformed but also the partizan (whose voting decision is not conditional on the state of the world) from the independent. In the following I will show that people who have an opinion (in the form of attachment to a party) are not necessarily better informed than others ${ }^{7}$.

Distinguishing between opinions and information has also clear normative implications: a higher turnout rate may improve the quality of democratic decisionmaking if it is driven by information. This is not necessarily the case if turnout is fostered by uninformed beliefs. In this paper I use therefore an objective measure of political knowledge and see how it affects the propensity to vote.

Finally, this paper is also related to the recent experimental evidence on voter mobilization by Gerber and Green (2000). They show that voter turnout is substantially increased by non-partizan personal canvassing. One possible interpretation of this result is that canvassing increases political awareness: at the very minimum, people are reminded of the coming election. By showing that political knowledge increases participation, this paper makes such interpretation quite plausible and, at the same time, shows that voters can be mobilized by information provided by the mass media.

\footnotetext{
${ }^{7}$ Lassen (2005) refers to a previous unpublished version of this paper and, correctly, points out that a "key instrument, readership of quality newspapers, could be related to unobserved heterogeneity". Overidentification tests support the use of that instrument, but such tests have notoriously low power. In this paper I do not make use of that instrument and all results remain unchanged.
} 


\section{Empirical specification}

In equation (1) I defined a citizen's net utility from voting as

$$
U_{0}=P B+D-C
$$

$U_{0}$ is a latent (unobservable) variable and turnout $T$ is a binary indicator such that $T=1$ if $U_{0}>0$ and $T=0$ if $U_{0} \leq 0$. We can approximate $U_{0}$ by using a linear random utility model:

$$
U_{0}=\boldsymbol{\beta}^{\prime} \mathbf{X}+\varepsilon
$$

where $\mathbf{X}$ is a vector of characteristics of the individual and of the environment ${ }^{8}$ (including $P$ ) and $\varepsilon$ is a white noise disturbance that includes the non-instrumental benefit $D^{9}$. We can then say that

$$
\operatorname{Pr}[T=1 \mid \mathbf{X}]=\operatorname{Pr}\left[\varepsilon<\beta^{\prime} \mathbf{X}\right]=\mathbf{F}\left(\beta^{\prime} \mathbf{X}\right)
$$

Assuming $\mathbf{F}(\cdot)$ is the standard normal distribution function, the (6) can be estimated by maximum likelihood probit.

Let us now introduce political information (Info) and define a new latent variable $U_{1}$ of the form

$$
U_{1}=\beta_{1} \operatorname{Info}+\boldsymbol{\beta}_{2}^{\prime} \mathbf{X}+\varepsilon
$$

We then have that

$$
\operatorname{Pr}[T=1 \mid \operatorname{Inf} o, \mathbf{X}]=\mathbf{F}\left(\beta_{1} \operatorname{Inf} o+\boldsymbol{\beta}_{2}^{\prime} \mathbf{X}\right)
$$

Estimating equation (8) is a correct procedure only if information acquisition is orthogonal to turnout. In the model of Feddersen and Pesendorfer (1996), for example, people are randomly informed or uninformed about the true state of the world, and therefore this estimation would be appropriate. However, as discussed in Section 2, information could be an endogenous explanatory variable in which case the coefficient estimates of (8) would be biased. To overcome this problem we

\footnotetext{
${ }^{8}$ This includes a vector of $1 \mathrm{~s}$, and therefore $\boldsymbol{\beta}^{\prime}$ includes a constant term.

${ }^{9}$ Some imperfect indicators of the sense of civic duty and interest in politics can be included in X. Such inclusion, however, does not change the results in any substantial way.
} 
estimate the following triangular system:

$$
\begin{aligned}
\text { Info } & =\boldsymbol{\alpha}_{1}^{\prime} \mathbf{X}+\boldsymbol{\alpha}_{2}^{\prime} \mathbf{Z}+u_{1} \\
U_{1} & =\beta_{1} \text { Info }+\boldsymbol{\beta}_{2}^{\prime} \mathbf{X}+u_{2}
\end{aligned}
$$

where $T=1$ if $U_{1}>0, T=0$ if $U_{1} \leq 0$, and $\mathbf{X}$ is again a vector of covariates representing individual and constituency characteristics which are assumed to affect both turnout and information acquisition. The identifying covariates are represented by the vector $\mathbf{Z}$. These explanatory variables are assumed to affect political knowledge but not directly the turnout decision. If this is the structural model, then simple probit estimates will clearly suffer endogeneity bias as the two error terms $u_{1}$ and $u_{2}$ are correlated. Thus, I use a two-step probit procedure. The first step consists of estimating the reduced form (9) by OLS and getting the residuals $\widehat{u}_{1}$. Our turnout equation will then be based on the following latent variable ${ }^{10}$ :

$$
T^{*}=\beta_{1}^{*} \operatorname{Info}+\boldsymbol{\beta}_{2}^{*^{\prime}} \mathbf{X}+\beta_{3}^{*} \widehat{u}_{1}+u_{2}^{*}
$$

This procedure provides both consistent (though not efficient) estimates of $\left(\beta_{1}^{*}, \boldsymbol{\beta}_{2}^{*}\right)$, as well as an endogeneity test to determine whether there is any overlap between the set of unobservables affecting equations (9) and (10). It consists of a simple t-test for the significance of the coefficient $\beta_{3}^{*}$ : we cannot reject the null hypothesis that Info is weakly exogenous in the turnout equation if $\beta_{3}^{*}$ is insignificant.

The estimated standard errors from this method are not correct but Monte Carlo evidence tend to show that the asymptotically correct standard errors are no more effective in large finite samples than the conditional standard errors (Bollen, Guilkey and Mroz, 1995). Nevertheless, to overcome any potential problems, standard errors of relevant variables have been estimated by bootstrap (with 1000 repetitions).

Finally we need to check the validity of the instruments. This can be done in several ways. One possibility is to compare a probit regression of turnout on all exogenous variables and instruments (unrestricted model) with the same regression where instruments are excluded but fitted values from the first stage regression are included (restricted model). Ideally, we would like the two to be similar. We can then perform a chi-square test based on the likelihood function. Another method,

\footnotetext{
${ }^{10}$ Define $Y=(X, Z)$ and consider the reduced form $U_{R}=\Pi Y_{i}+v$. Then indicating with $\sigma_{2}$ the standard deviation of $v$, we have that the estimable structural equation is based on the variable $T^{*}=B_{1} / \sigma_{2}$. For further details see Maddala (1983).
} 
based on a Wald test, consists in checking the joint significance of the instruments in the turnout equation. If information is not included this is always a valid test. If information is found to be exogenous then another method becomes available. I illustrate this test in section 5, where results are presented.

\section{The data}

I use data from the 1997 general election in Great Britain ${ }^{11}$. The United Kingdom is a parliamentary system in which members of parliament are elected one in each electoral constituency using a first past the post rule. Two major parties, Conservative and Labour, compete to obtain a majority in the parliament, and therefore control of the government. A number of other parties, however, present their candidates in most constituencies and some manage to win seats in parliament. In particular, the Liberal-Democratic party is a well established national third force, while, in Scotland and Wales, nationalist parties tend to win normally more seats than the Conservatives. In 1997 the Labour party obtained a significant victory after four consecutive Conservative terms.

The main source of data used in this paper is the 1997 British General Election Study (BES). This study collects data from face to face interviews that were conducted shortly after the election, with approximately $90 \%$ of the fieldwork completed within six weeks of the election date. The response rate was $62 \%$, resulting in an overall sample of 3615 voters. However, I have been forced to drop a number of observations since some respondents refused to answer relevant questions (particularly about income). In most cases I use a sample of 2882 registered voters ${ }^{12}$.

A very important problem faced by studies on turnout is that most surveys tend to overrepresent the turnout rate. This is essentially due to two reasons: first, people tend to declare that they voted even if they did not and, second, people that participate in elections tend also to be more willing to take part in surveys. Our dataset does not suffer from the first type of bias: turnout was verified by using the electoral register. I rely on self-reported information only when verified turnout is

\footnotetext{
${ }^{11}$ This means England, Scotland and Wales. Northern Ireland has a substantially different political situation from the rest of the country and it is customarily surveyed separately.

${ }^{12}$ The qualifying date for electoral registration expired several months before the election day (10th October 1996). We are interested in information acquisition and turnout of potential voters; clearly the motivation to acquire information of non-registered voters is different. Thus, only registered voters are considered here. This implies dropping a limited number of observations. All estimations have been replicated including those observations and no relevant changes have been noticed.
} 
not available. This is the case for 415 observations (or $14.4 \%$ of the sample), among which the turnout rate $(72.3 \%)$ is very close to the official turnout rate for that election (71.5\%). As can be seen from Table 1, there are 109 respondents in the sample that declared to have voted when in fact they did not and 18 voters that declared to have not voted when in fact they did. This shows that using verified turnout makes an important difference.

The second type of bias, although much harder to avoid, appears to be limited. Our sample displays an overall $78.2 \%$ turnout while official turnout was $71.5 \%$. However, when the official turnout is adjusted to take into account of the inaccuracies in the electoral register at the time of the election ${ }^{13}$ this figure raises to $74 \%$ (Denver, 2003), so that the actual bias is just slightly above $4 \%$.

A special feature of the 1997 BES is to include a higher number of voters from ethnic minorities and Scotland. This makes the use of the population weights absolutely crucial if we want the sample to be representative of the British citizenry ${ }^{14}$. Unweighted regressions (not reported) tend however to deliver similar results.

The starting point of this analysis is to measure political knowledge. Clearly, the range of issues and facts that are relevant to politics is extremely large, so how can we gauge political knowledge? What is relevant and what is not? Is there any risk to bias the assessment with our priors? Delli Carpini \& Keeter (1996), in presenting evidence on the political knowledge of American voters, based their analysis on nearly 3700 questions collected in various surveys. They concluded that "researchers developing national or general political knowledge scales need not be overly concerned with the mix of specific topics covered by individual items. Scales made up of items tapping only knowledge of institutions and processes, substantive issues, or public figures are likely to serve as reasonable measures of the overarching construct" ${ }^{15}$. This is extremely important in this case: the empirical analysis I present is based on a limited set of questions but correct answers to such questions are likely to be correlated with the knowledge of other political issues.

The 1997 BES is well suited for the purpose of this study because it contains two sets of questions which help to establish how much respondents know about British politics. In the first set of questions respondents were asked to write down as many candidates' names in their constituency as they could remember (with a

\footnotetext{
${ }^{13}$ The electoral register is compiled several months before the election. The official turnout rate refers to the population on the register and is therefore not totally accurate.

${ }^{14}$ As usual, these weights also take into account of the different selection probabilities and rates of response.

${ }^{15}$ Delli Carpini and Keeter (1996), p.174.
} 
maximum of six). The answers have then been reconciled with the actual list of candidates. In the second set of questions, respondents received seven statements on the British political and institutional system and were asked to say if these were true or false ${ }^{16}$. To measure political knowledge I give a point for each correct answer in the first set of questions and a score of 0.66 for each correct answer in the second set of questions ${ }^{17}$. I then add the scores each respondent obtains to form a variable (Info) that I use as a measure of political knowledge. A kernel estimate of Info is reported in Fig. 1, where the dashed line represents a normal distribution with the same mean and variance of Info: it is evident that political knowledge is approximately normally distributed.

The BES also includes questions on a number of economic and socio-demographic individual characteristics that I use as control variables. I also use data from the 1991 Census to control for the possible influence on turnout of the characteristics of the local environment, like marginality, social norms etc ${ }^{18}$.

In general, I attempt to include all the variables that, for different reasons, have been found to be relevant by the empirical literature on turnout ${ }^{19}$. For this reason the list of variables employed in this study is long, and the standard errors are often high because of multicollinearity. Nevertheless, this strategy leads to robust results for what concerns the variables we are interested in.

One important issue concerns the use of political attitude variables, such as a person's interest in politics, her attachment to a specific party and her ideological self-placement on the left-right dimension. These variables have been found to be important predictors of electoral turnout. Moreover, they can capture some of the unobserved heterogeneity that drives both turnout and political knowledge, and their inclusion in the turnout equation should limit the omitted variables problem. Nevertheless, there are good reasons to be cautious about their use. Answers to this sort of questions can be an ex-post rationalization of voting behaviour. Moreover, it has been shown that responses to this type of questions are sometimes sensitive to the order in which the questions are posed $^{20}$. This casts doubts on the overall reliability of such indicators. Thus, I perform my analysis both with the political

\footnotetext{
${ }^{16}$ Statements are reported in the Data appendix.

${ }^{17}$ The different weight is derived by Bayes rule: see the Data appendix for details.

${ }^{18}$ Data from the Census are at the level of Districts, local administration units reported in the BGES.

${ }^{19}$ See for example Matsusaka and Palda, (1999), and, for a study of the U.K, Swaddle and Heath (1989).

${ }^{20}$ See for example Bishop, Oldendick, and Tuchfarber (1984) and Abramson, Silver, and Anderson (1987).
} 
attitude variables and without. As an alternative I use other, imperfect but more objective, indicators, like the awareness of being registered, the fact of reading a quality morning newspaper regularly and whether the respondent voted or not in the previous election. Results turn out not to be sensitive to the inclusion or not of political disposition variables.

Finally, I now describe the instrumental variables, i.e. the vector $\mathbf{Z}$ in equation (9). I use three variables that I consider to influence information acquisition but not directly turnout. The first instrument is represented by a dummy variable (bigshot) equal to 1 when a nationally famous politician is candidate in the constituency. I define as big shots all the current and past members of cabinet, the members of the Labour "shadow-cabinet" 21 and the leader of the third major party (Liberal Democratic), Paddy Ashdown. I assume that these politicians are better known by the public than all the other candidates. Therefore, voters from those electoral constituencies should have better information on candidates. The second instrument (Salience) attempts to capture the salience on media of each electoral constituency during the campaign. For this purpose I refer to the content of three major national newspapers ${ }^{22}$ during the thirty days preceding the election. Salience consists of a dummy equal to 1 if a constituency (or any of its candidates) has received above average coverage in these newspapers but is not included in bigshot. My assumption is that people living in more salient constituencies are more exposed to political information and therefore, keeping other things equal, will know more about candidates and platforms in the day of the election. The third instrument is a dummy variable ( $b b c 100)$ equal to 1 for citizens living in constituencies that the BBC defined as "the battleground" and on which the BBC decided to focus its attention on the night of the election: they were the expected closest 100 Consevative-held constituencies (and therefore the decisive ones as in 1997 a swing against the Conservatives was expected). I expect these constituencies to get larger media coverage during the electoral campaign and, possibly, a more intense effort by parties in making candidates and platforms known to the public.

Data description and summary statistics are reported in the Data appendix.

\footnotetext{
${ }^{21}$ A "shadow-cabinet" is put in place by the main opposition party and is composed of those who, in case of victory, are most likely to become members of the cabinet. A shadow foreign secretary, for example, follows very closely the government foreign policy and is supposed to be able to control, comment and propose alternatives to the foreign policy of the government. This makes shadow-cabinet members quite popular on the media.

${ }^{22}$ The Times, The Guardian and The Independent.
} 


\section{Results}

To make this analysis comparable with previous studies of turnout, I start by estimating a standard turnout equation. The results are reported in Table 2. Column 1 contains the results when income, education and church attendance are numerical variables while in column 2 they are considered as categorical variables. A comparison of the log-likelihood scores shows that I cannot accept the restriction imposed under the first specification and, therefore, in the subsequent analysis I always consider income, education and church attendance as categorical dummies.

I find that the propensity to vote increases with income, and is significantly larger for people who are married, who have been contacted by a canvasser ${ }^{23}$ and who are aware of being on the electoral register. More surprisingly, I find that a number of individual variables like education, gender and age, are not significant. It should be noted, however, that columns 1 and 2 include past voting behaviour, i.e. whether the respondent voted or not in the previous general election. This aims at capturing relevant individual-specific unobservables and probably absorbs most of the impact of other variables (whose parameters represent therefore variations with respect to this individual fixed effect). Moreover, to capture unobservable environmental characteristics I include aggregate turnout, which is also likely to absorb the effect of other constituency-level variables.

Column 3 presents a more parsimonious model where past voting behaviour and aggregate turnout have been excluded. The resulting estimates have a decidedly more familiar flavour. Consistent with previous findings on the determinants of turnout in British elections (Crewe, Fox and Alt, 1977; Swaddle and Heath, 1989; Denver 2003), my estimates show that income, marital status, housing tenure and residential mobility are, together with the respondent's age, very good predictors of turnout, while education and gender seem to have little impact ${ }^{24}$. Column 4 includes political attitude variables which, not surprisingly, have a very strong explanatory power. Thus, the data offer no major surprises. Before proceeding, it is worth noting the negative impact of having a full time job on the propensity to vote $^{25}$ and the little impact of the constituency-level variables, even when aggregate

\footnotetext{
${ }^{23}$ If we separate face-to-face canvassing from telephone calls we find that the first is vastly more effective (not reported). This confirms what has been found by Gerber and Green (2000) for the United States.

${ }^{24}$ Milligan et al. (2003) find that the impact of education is especially strong on registration. Conditional on being registered, this effect disappears. It is therefore not surprising that education tends to be insignificant in Britain, where compiling the register is the responsibility of local authorities. Our sample contains, anyway, only registered voters.

${ }^{25}$ Thus, voting on a working day (Thursday) may have an impact on the decision to vote.
} 
turnout is not included.

Table 3 reports estimates of the turnout equation when information is included. It is immediately clear that information is a strong predictor of turnout. Both the magnitude and the significance level of the coefficient seem to suggest that information is amongst the most important explanatory variables of electoral participation. In the simple probit estimates of column 1, increasing information by one standard deviation above the mean renders a voter approximately $6 \%$ more likely to participate. This effect is strong and robust to variations in the specification adopted. I obtain very similar estimates whether or not I include the respondents' self assessment of their political interest, ideological position and party attachment.

The two step probit also shows a positive impact of information on turnout. Estimation is this time less precise ${ }^{26}$, but the magnitude of the coefficient is much larger. In this case increasing information by one standard deviation above the mean raises the probability to vote by approximately $13 \%$. Once again, introducing disposition variables does not produce any relevant changes. Figure 2 reports the probability of voting associated with the estimates of columns 1 and 3 in Table $3^{27}$ : the impact of information is dramatically stronger when I use the two-step procedure.

Although it seems now beyond any doubt that political knowledge increases turnout, if we want to quantify such impact, which estimates should we use? Looking at the coefficient of the first stage residuals in columns 3 and 4 , the null hypothesis that information is weakly exogenous in the turnout equation cannot be rejected. This result should be interpreted with some caution, as it is clear that residuals, although not significant at the $10 \%$ level, are still not totally unrelated to turnout. More importantly, not rejecting exogeneity does not mean that there are no variables driving both turnout and information. It means, however, that including the standard controls used in studies of turnout, we can probably be reassured that there are no omitted variables left in the residuals that are correlated with information. Controlling for past voting behaviour is, for example, important to capture unobserved heterogeneity. Including political disposition variables is, instead, not essential.

The instruments I use pass comfortably the overidentification tests presented in the previous section and shown in Table 4. Twice the difference between the loglikelihood of the equations in the first and the second columns (where, respectively,

\footnotetext{
${ }^{26}$ The significance level is, however, still very close to $5 \%$.

${ }^{27}$ Including disposition variables would change the graphic only marginally.
} 
the instrumental variables and the first stage fitted values are included) is equal to 0.28 and a chi-test is easily passed. The corresponding statistic when I include disposition variables is 0.19 and again a chi-test is passed. Table 4 also reports the Wald tests for the exclusion of bigshot, bbc100 and salience from the turnout equation (where information is not included): these deliver similar outcomes. To these, we can add a further test if, like in this case, exogeneity cannot be rejected: the validity of the instruments can be checked by including in the turnout equation both information and the three instrumental variables. If instruments are valid then this equation should be not too different from the restricted model when the three instruments are excluded. The results (both a log-likelihood ratio and a Wald test) are reported at the bottom of columns 3 and 6 for, respectively, the equations with and without disposition variables. They also show that the three instruments are not directly related to turnout. Hence, all this seems to suggest that the instrumental variables have been well chosen and that the endogeneity test reported in Table 3 is valid.

Before concluding this section it is useful to look at the first stage regressions, which, although in a reduced form, give an indication of the propensity of British voters to be informed about politics (Table 5). First of all, the instruments are significant and show the expected signs. This suggests that mass media coverage and the overall strategic importance of a constituency during an electoral campaign make voters more informed. Thus, exposure to relevant information matters.

Among other exogenous variables, both education and income are very strong predictors of political knowledge. This result is obtained in spite of controlling for a number of covariates that are normally used to explain income. A number of other socio-demographic and economic characteristics are also good predictors of the voter political knowledge. Age, gender, the length of residence in a given constituency and union membership all display sizeable and significant effects. Interestingly, the results show that the time constraint matters, as it affects the ability to gather information: while retired voters tend to be better informed than average, the opposite is true for voters in full time occupation.

In contrast with what we found in the turnout equation, constituency-level variables are good predictors of political knowledge: voters are substantially more informed in constituencies with closer competitions. This is clearly compatible with the fact that politicians and parties put more effort in marginal constituencies (as suggested for example in Aldrich, 1993, and Shachar and Nalebuff, 1999). However, an alternative interpretation is possible: that individual demand for political 
information increases when the probability to be a pivotal voter is higher. A quite surprising result is that political knowledge is higher in constituencies with more unemployment.

Finally, political disposition variables have a large impact on political knowledge: voters that declare to have a strong interest in politics are better informed. The same is true of voters that pose themselves at extreme points on the left-right scale. However, voters that show a strong attachment to a party tend to be less informed. This stresses the importance of distinguishing between objective knowledge and opinions, especially if one wants to derive normative statements about the desirability of an informed public opinion and of a participative citizenry.

\section{Concluding remarks}

Does political knowledge affect the propensity of citizens to vote? The conclusion of this paper is that it does. Analysing data from the 1997 British general election I find not only that information is a good predictor of turnout, but also that it raises voter participation in a clearly causal fashion. An increase equal to one standard deviation from the mean in our measure of political knowledge raises the probability that a person votes by at least $6 \%$ (with other variables kept constant at their mean). A person with maximum knowledge is, other things equal, approximately one third more likely to vote than a person at the bottom of the knowledge distribution. This is a sizeable effect.

I also derive results on the determinants of voters' political knowledge and show that a number of socio-demographic variables with little direct impact on turnout (like education and gender) can actually have a vast impact on it through their effect on political knowledge. This, together with the finding that income is an important predictor of knowledge, implies that political representation is probably even more socioeconomically biased of what previous studies of turnout could reveal. I also show that political salience and the coverage given by mass media play a very important role in increasing voters' knowledge of political matters, in spite of their negligible direct impact on turnout. This seems to suggest that the limited impact of mass media on voting behaviour encountered in a number of studies could be due to misspecification in the estimated equations.

Finally, I would like to conclude with some normative remarks on the link between my results and the findings of recent formal models of information aggregation. The availability of information increases the turnout of informed voters in 
elections, thus making it more likely that the process of collective decision making leads to desirable outcomes. Hence, although not included in formal definitions of what democracy consists of, an informed public opinion and an accurate transmission of information on the mass media improve the quality of democratic governance.

\section{References}

[1] Abramson, P.R., B.D. Silver, and B.A. Anderson. 1987. "The Effects of Question Order in Attitude Surveys: the Case of the SRC/CPS Citizen Duty Items". American Journal of Political Science 31: 900-908.

[2] Aldrich, J.H. 1993. "Rational Choice and Turnout". American Journal of Political Science 37: 246-278.

[3] Austen-Smith, D. 1990. "Information Transmission in Debate". American Journal of Political Science 34:124-152.

[4] Besley, T. and A. Case. 2003. "Political Institutions and Policy Choices: Evidence from the United States". Journal of Economic Literature XLI: 7-73.

[5] Bishop, G.F., R.W. Oldendick, and A.J. Tuchfarber. 1984. "Interest in Political Campaigns: the Influence of Question Order and Electoral Context". Political Behaviour 6: 159-169.

[6] Bollen, K.A., D.K. Guilkey, D.K., and T.A. Mroz. 1995. "Binary Outcomes and Endogenous Explanatory Variables: Tests and Solutions with an Applications to the Demand for Contraceptive Use in Tunisia". Demography 32: 111-131.

[7] Boothroyd, D. 2002. "United Kingdom Election Results", http://www.election.demon.co.uk/.

[8] Calvert, R.L.1985. "Robustness of the Multidimensional Voting Model: Candidate Motivations, Uncertainty and Convergence". American Journal of Political Science 29 (1): 69-95.

[9] Coupé, T. and A.G. Noury. 2004. "Choosing not to choose: on the link between information and abstention". Economics Letters 84: 261-265. 
[10] Cox, G.W. and M.C. Munger. 1989. "Closeness, Expenditure, Turnout: The 1982 U.S. House Elections". American Political Science Review 83: 217-32.

[11] Crewe, I., A. Fox and J. Alt 1977. "Non-voting in British general elections 1966-October 1974". In British Political Sociology Yearbook, Vol. 3, ed. C. Crouch. London: Croom Helm, 38-109.

[12] Delli Carpini, M.X. and S. Keeter. 1996. What Americans Know about Politics and Why It Matters, Yale University Press.

[13] Denver, D. 2003. Elections and voters in Britain. Palgrave McMillan.

[14] Feddersen, T.J. and W. Pesendorfer. 1996. "The Swing's Voter's Curse". American Economic Review 86: 408-424.

[15] Feddersen, T.J. and W. Pesendorfer. 1999. "Abstention in Elections with Asymmetric Information and Diverse Preferences". American Political Science Review 93: 381-398.

[16] Ferejohn, J. 1986. "Incumbent Performance and Electoral Control". Public Choice 50: 5-26.

[17] Gerber, A.S. and D.P. Green. 2000. "The Effects of Personal Canvassing, Telephone Calls, and Direct Mail on Voter Turnout: A Field Experiment". American Political Science Review 94: 653-63.

[18] Ghirardato, P. and J.N. Katz. 2002. "Indecision Theory: Quality of Information and Voting Behaviour". Social Science Working Paper 1106R, California Institute of Technology.

[19] Grofman, B. and B. Norrander. 1990. "Efficient Use of Reference Group Cues in a Single Dimension". Public Choice 64: 213-217.

[20] Heath, A., R. Jowell, J.K. Curtice and P. Norris. 1999. "The British General Election Study, 1997", available at http://www.data-archive.ac.uk/.

[21] Hicks, A.M. and Swank, D.H.1992. "Politics, Institutions, and Welfare Spending in Industrialized Democracies, 1960-1982". American Political Science Review 86: 658-674.

[22] Hill, K.Q. and Leighley, J.E.1992. "The Policy Consequences of Class Bias in State Electorates". American Journal of Political Science 36: 351-365. 
[23] Hill, K.Q., Leighley, J.E. and Hinton-Andersson, A.1995. "Lower Class Mobilization and Policy Linkage in the US States". American Journal of Political Science 39: 75-86.

[24] Husted, T.A. and Kenny, L.W. 1997. "The Effect of the Expansion of the Voting Franchise on the Size of Government". Journal of Political Economy 105: $54-82$.

[25] Lassen, D.D. 2005. "The Effect of Information on Voter Turnout: Evidence from a Natural Experiment." American Journal of Political Science, forthcoming.

[26] Leighley, J.E. and J. Nagler. 1992. "Individual and Systemic Influences on Turnout: Who Votes? 1984". The Journal of Politics 54: 718-740.

[27] Levitt, D. Steven, and James J. Snyder. 1995. Political Parties and the Distribution of Federal Outlays". American Journal of Political Science 39: 958-980.

[28] Lindert, P.1996. "What Limits Social Spending?". Explorations in Economic History 33: 1-34.

[29] Lupia, A. 1992. "Busy Voters, Agenda Control, and the Power of Information". American Political Science Review 86: 390-404.

[30] Lupia, A. 1994. "Shortcuts Versus Encyclopedias: Information and Voting Behaviour in California Insurance Reform Elections". American Political Science Review 88: 63-76.

[31] Lupia, A. and M.D. McCubbins. 1998. The Democratic Dilemma: Can Citizens Learn What They Need to Know? New York: Cambridge University Press.

[32] Luskin, R. C. 1990. "Explaining Political Sophistication". Political Behavior 12: $331-361$.

[33] Maddala, G. 1983. Limited Dependent and Qualitative Variables in Econometrics. New York: Cambridge University Press.

[34] Matsusaka, J.G. 1995. "Explaining Voter Turnout Patterns: an Information Theory". Public Choice 84: 91-117. 
[35] Matsusaka, J.G. and F. Palda. 1999. "Voter Turnout: How Much Can we Explain?". Public Choice 98: 431-446.

[36] McKelvey, R.D. and P.C. Ordeshook. 1984. "Rational Expectations in Elections: Some Experimental Results Based on a Multidimensional Model". Public Choice 44: 61-102.

[37] Palfrey, T.R.and K.T. Poole. 1987. "The Relationship Between Information, Ideology, and Voting Behavior". American Journal of Political Science 31: 511-530.

[38] Patterson, S.C. and G.A. Caldeira. 1983. "Getting Out the Vote: Participation in Gubernatorial Elections". American Political Science Review 77: 675-689.

[39] Peterson, P.E. and Rom, M. 1989. "American Federalism, Welfare Policies, and Residential Choices". American Political Science Review 83: 711-28.

[40] Popkin, S.L. 1991. The Reasoning Voter. Chicago: The University of Chicago Press.

[41] Riker, W.H. and P.C. Ordeshook. 1968. "A Theory of the Calculus of Voting". American Political Science Review 62: 25-42.

[42] Sanders, M.S. 2001. "Uncertainty and Turnout", Political Analysis 9: 45-57.

[43] Shachar, R. and B. Nalebuff. 1999. "Follow the Leader: Theory and Evidence on Political Participation". American Economic Review, 89: 525-547.

[44] Sniderman, P.M., R.A. Brody, and P.E. Tetlock. 1991. Reasoning and Choice: Explorations in Political Psychology. New York: Cambridge University Press.

[45] Sobel J. 1985. "A Theory of Credibility", Review of Economic Studies 52: 557-573.

[46] Stromberg, D. 2004. "Radio Impact on Public Spending". Quarterly Journal of Economics 119: 189-221.

[47] Swaddle, K. and A. Heath. 1989. "Official and reported turnout in the British general election of 1987". British Journal of Political Science 19: 537-51.

[48] Young, P. 1988. "Condorcet's theory of voting". Americal Political Science Review 82: 1231-44. 
[49] Wattenberg, M., I. McAllister and A. Salvanto. 2000. "How Voting is Like Taking a SAT test - an analysis of American voter roloff". American Politics Quarterly 28: 234-250.

[50] Wittman, D.A. 1995. The myth of democratic failure: why political institutions are efficient. Chicago: University of Chicago Press.

[51] Wolfinger, R.E. and S.J. Rosenstone, 1980. Who Votes? New Haven: Yale University Press. 


\section{Data Appendix}

If not otherwise specified, variables are derived from the 1997 British General Election Study.

\section{- Information.}

The variable Info has been constructed by using the following two questions:

1. Do you happen to remember the names of any candidates who stood in your constituency in the general election this year?

Please write in all the names of candidates that you can remember (6 spaces provided) or tick box: I can't remember any of the candidates' names.

Note: the names of candidates written in by respondents were checked against official lists of candidates.

2. Political knowledge quiz (answers: true/false/don't know):

a: Margaret Thatcher was a Conservative Prime Minister;

b: The number of MP is about 100;

c: The longest time allowed between general elections is four years;

d: Britain's electoral system is based on proportional representation;

e: MPs from different parties are on parliamentary committees;

f: Britain has separate elections for the European parliament and the British parliament;

g: No-one may stand for parliament unless they pay a deposit.

Let us define with names the number of candidates correctly reported and with quiz the number of correct answers in question 2. In $f o$ is then given by

$$
\text { Info }=\text { names }+0.66 \times q u i z
$$

Quiz has been downweighted because, being a true /false questions, it was possible for respondents to guess the answer without knowing it. Using Bayes rule we have (assuming the prior probability of a correct answer is 0.5 ):

$$
\operatorname{Pr}(\text { know } \mid \text { correct })=\frac{\operatorname{Pr}(\text { correct } \mid \text { know })}{\operatorname{Pr}(\text { correct } \mid \text { know })+\operatorname{Pr}(\text { correct } \mid \text { don't })}=\frac{1}{1+0.5}=0.66
$$

- Turnout: Voters' verified turnout. Reported turnout has been used for respondents whose turnout has not been verified. These are approximately $15 \%$ of the sample. Turnout $=1$ means that the respondent voted.

- Income. Total household income from all sources before tax. Categorical variable from 1 to 16 . 
- Age. respondent's age. Age2 is defined as the square of age divided by 100 .

- Gender. Respondent's gender, equal to 1 if male.

- Education. Respondent's education level. Categorical variable from 1 to 7.

- Married. Respondent's marital status, equal to 1 if "married" or "living as married".

- Ethnicity dummies. "To which of these groups do you consider you belong?". The variable asian is equal to 1 if the answer is one of "Indian, Pakistani, Bangladeshi, Chinese, Other Asian". The variable black is equal to 1 if the answer is one of "Black African, Black Caribbean, Other Black".

- Churchgoer. Categorical variable derived from the question: "Apart from such special occasions as weddings, funerals and baptisms and son on, how often do you attend services or meetings connected with your religion?", with answers going from "no religion or never or practically never attends" to "once a week or more".

- Length of residence. Answer to: "How long have you lived in this neighbourhood?" (in years).

- Full time job. Dummy variable equal to 1 if the respondent works regularly 30 hours per week or more.

- house owner. Dummy variable equal to 1 if the respondent's household owns their accommodation."

- Canvasser. Dummy variable equal to 1 if a positive answer is given to "Did a canvasser from any party call at your home to talk to you during the electoral campaign?" and/or "Were you contacted by anyone on the telephone during the electoral campaign asking how you might vote?".

- Voted in 1992. Dummy variable equal to one if the respondent voted in the 1992 general election (self reported).

- Quality paper reader. Dummy variable equal to one 1 if the respondent declares ro regularly read a daily morning newspaper and, to the question "which daily morning newspaper do you read most often?", answers one of the following: The Daily Telegraph, The Financial Times; The Guardian; The Independent; The Times.

- Retired. Dummy variable equal to one if the respondent declares to be "wholly retired from work".

- Union. Dummy variable equal to one if the respondent, or his/her partner, is, or has been in the past, member of a union.

- Ideological strenght. Variable derived from the respondent's ideological 
self-placement on a 0 (left) to 10 (right) scale. The ideological strenght is posed equal to 0 if the position of the left-right dimension is 5 , is equal to 1 if the position on the left-right dimension is either 4 or 6 , etc. Respondents who answered "can't choose" have an ideological strenght equal to 0.

- Party attachment. Dummy variable equal to 1 if the respondent declares to be very strongly attached to a party or if the respondent declares to have voted always the same party.

- Degrees. Ratio of the population in the district with a degree (source: Census 1991).but not higher education qualifications.

- Unemployment. Ratio of unemployed population in the district (source: Census 1991).

- Population density. Persons per hectare in the district (source: Census 1991).

- Aggregate turnout. Percentage turnout in the constituency in 1997 election (source: Boothroyd, 2002).

- Marginality. Define with W and R the percentage of votes reported respectively by the winning candidate and the runner up. Then Marginality = $(W-R) /(W+R)$ (source: Boothroyd, 2002).

- Bbc100. Dummy equal to 1 if the constituency was included among the 100 decisive constituencies ("the battleground") according to the BBC (source: BBC web page).

- Big shot. Dummy equal to 1 if one of the candidates in the constituency is a current or former member of cabinet, a current member of the shadow-cabinet or the leader of the Liberal-Democratic party.

- Salience. Dummy variable equal to 1 a constituency is found to have been "salient" on national newspapers during the last 30 days of the electoral campaign, but not included in bigshot. The number of articles mentioning one of the candidates has been collected from three national newspapers (The Guardian, The Independent and The Times). These have been weighted by the inverse of the total political articles appeared in each newspaper durimng the same period and then averaged. A constituency (in the sense of any of its candidates) is defined as being salient if it has been mentioned in a number of articles which is above the average (source: author's elaboration on data from the Guardian, the Independent and The Times). 
Tab. 1 Self-reported and verified turnout

\begin{tabular}{|l|ccc|c|}
\hline & Yes & $\frac{2}{\text { Verified }}$ No & Not Known & Tot \\
\hline Self-Rep. & & & & \\
Yes & 1952 & 109 & 300 & 2361 \\
No & 18 & 387 & 115 & 520 \\
Don't Knov & 0 & 1 & 0 & 1 \\
\hline Tot & 1970 & 497 & 415 & 2882 \\
\hline
\end{tabular}


Fig.1: The distribution of information

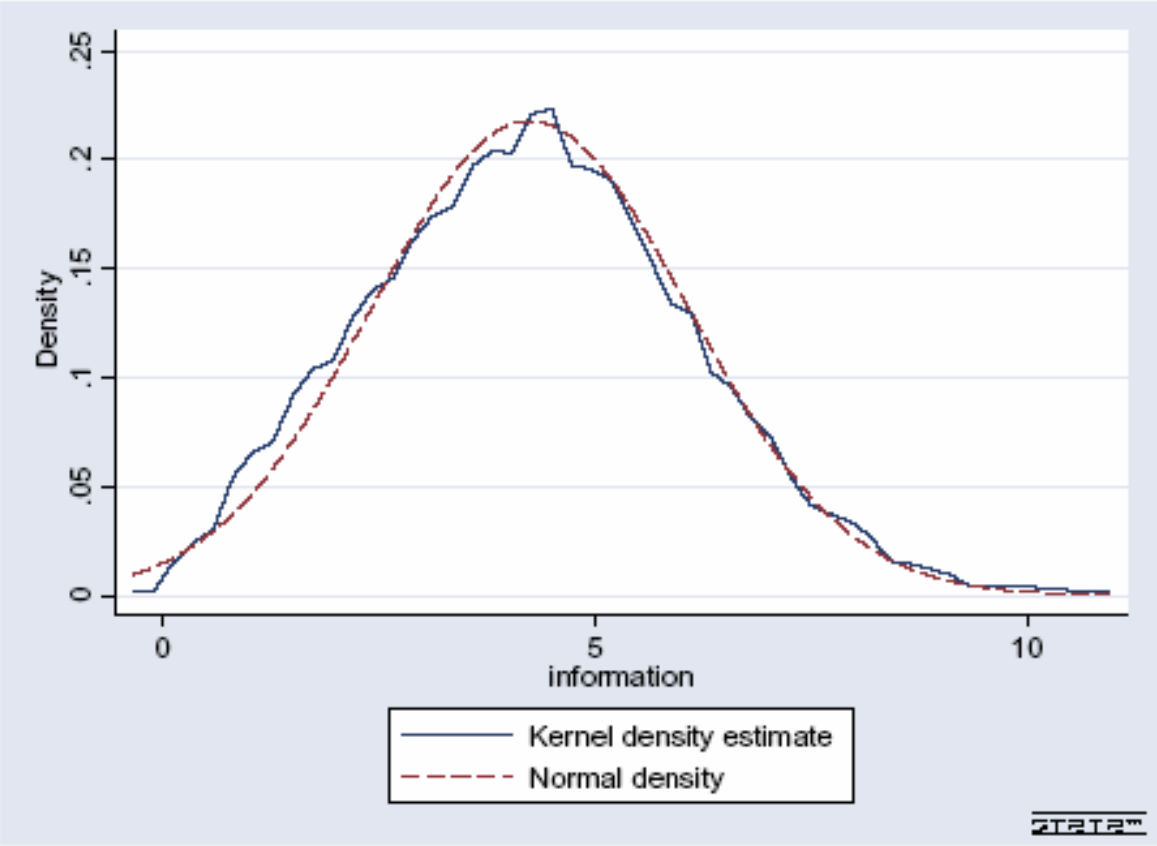


Tab. 2: Probit Estimates of Turnout

\begin{tabular}{|c|c|c|c|c|c|}
\hline Dependent variable: Turnout & $(1)$ & $(2)$ & $(3)$ & $(4)$ & (5) \\
\hline age & $\begin{array}{c}-0.002 \\
(0.72)\end{array}$ & $\begin{array}{c}-0.002 \\
(0.67)\end{array}$ & $\begin{array}{c}-0.002 \\
(0.48)\end{array}$ & $\begin{array}{c}0.006^{\star \star} \\
(1.98)\end{array}$ & $\begin{array}{c}-0.001 \\
(0.20)\end{array}$ \\
\hline age2 & $\begin{array}{l}0.003 \\
(0.89)\end{array}$ & $\begin{array}{l}0.003 \\
(0.84)\end{array}$ & $\begin{array}{l}0.002 \\
(0.64)\end{array}$ & $\begin{array}{c}-0.004 \\
(1.11)\end{array}$ & $\begin{array}{c}0.0003 \\
(0.10)\end{array}$ \\
\hline married & $\begin{array}{c}0.052^{\star \star} \\
(2.55)\end{array}$ & $\begin{array}{c}0.052^{\star *} \\
(2.56)\end{array}$ & $\begin{array}{c}0.044^{\star \star} \\
(2.12)\end{array}$ & $\begin{array}{c}0.058^{\star \star \star} \\
(2.77)\end{array}$ & $\begin{array}{c}0.042^{\star *} \\
(2.08)\end{array}$ \\
\hline gender & $\begin{array}{c}-0.021 \\
(1.10)\end{array}$ & $\begin{array}{c}-0.020 \\
(1.05)\end{array}$ & $\begin{array}{c}-0.022 \\
(1.18)\end{array}$ & $\begin{array}{c}-0.029 \\
(1.48)\end{array}$ & $\begin{array}{c}-0.024 \\
(1.24)\end{array}$ \\
\hline asian & $\begin{array}{l}0.080 \\
(1.32)\end{array}$ & $\begin{array}{l}0.083 \\
(1.39)\end{array}$ & $\begin{array}{l}0.077 \\
(1.36)\end{array}$ & $\begin{array}{l}0.041 \\
(0.63)\end{array}$ & $\begin{array}{l}0.043 \\
(0.72)\end{array}$ \\
\hline black & $\begin{array}{c}-0.016 \\
(0.16)\end{array}$ & $\begin{array}{c}-0.007 \\
(0.07)\end{array}$ & $\begin{array}{c}-0.026 \\
(0.25)\end{array}$ & $\begin{array}{l}0.0002 \\
(0.002)\end{array}$ & $\begin{array}{c}-0.125 \\
(0.92)\end{array}$ \\
\hline union member & $\begin{array}{l}0.019 \\
(1.00)\end{array}$ & $\begin{array}{l}0.019 \\
(0.99)\end{array}$ & $\begin{array}{l}0.013 \\
(0.73)\end{array}$ & $\begin{array}{l}0.021 \\
(1.12)\end{array}$ & $\begin{array}{l}0.010 \\
(0.56)\end{array}$ \\
\hline length of residence & $\begin{array}{c}0.001 * \\
(1.80)\end{array}$ & $\begin{array}{c}0.001^{*} \\
(1.80)\end{array}$ & $\begin{array}{c}0.001 * \\
(1.89)\end{array}$ & $\begin{array}{c}0.001^{\star \star} \\
(2.20)\end{array}$ & $\begin{array}{c}0.001 * \\
(1.73)\end{array}$ \\
\hline full time job & $\begin{array}{c}-0.034 \\
(1.45)\end{array}$ & $\begin{array}{c}-0.035 \\
(1.50)\end{array}$ & $\begin{array}{c}-0.036 \\
(1.61)\end{array}$ & $\begin{array}{c}-0.022 \\
(0.94)\end{array}$ & $\begin{array}{c}-0.038 * \\
(1.69)\end{array}$ \\
\hline house owner & $\begin{array}{l}0.031 \\
(1.40)\end{array}$ & $\begin{array}{l}0.030 \\
(1.36)\end{array}$ & $\begin{array}{l}0.034 \\
(1.52)\end{array}$ & $\begin{array}{c}0.045^{\star \star} \\
(2.05)\end{array}$ & $\begin{array}{c}0.037^{* *} \\
(1.99)\end{array}$ \\
\hline quality newspaper reader & $\begin{array}{l}0.046 \\
(1.57)\end{array}$ & $\begin{array}{l}0.046 \\
(1.57)\end{array}$ & $\begin{array}{l}0.047 \\
(1.62)\end{array}$ & $\begin{array}{l}0.040 \\
(1.37)\end{array}$ & $\begin{array}{l}0.010 \\
(0.31)\end{array}$ \\
\hline canvasser & $\begin{array}{c}0.066^{\star \star \star} \\
(3.39)\end{array}$ & $\begin{array}{c}0.065^{\star \star *} \\
(3.33)\end{array}$ & $\begin{array}{c}0.065^{\star \star \star} \\
(3.40)\end{array}$ & $\begin{array}{c}0.064^{\star \star \star} \\
(3.32)\end{array}$ & $\begin{array}{c}0.058^{\star \star *} \\
(3.04)\end{array}$ \\
\hline voted in 1992 & $\begin{array}{c}0.273^{\star \star \star} \\
(10.23)\end{array}$ & $\begin{array}{c}0.272^{\star \star \star} \\
(10.20)\end{array}$ & $\begin{array}{c}0.273^{\star \star \star} \\
(10.39)\end{array}$ & & $\begin{array}{c}0.209 * \star * \\
(8.23)\end{array}$ \\
\hline aware of being registered & $\begin{array}{c}0.701^{\star \star \star} \\
(4.67)\end{array}$ & $\begin{array}{c}0.700^{\star * \star} \\
(4.63)\end{array}$ & $\begin{array}{c}0.711^{\star \star \star} \\
(4.41)\end{array}$ & $\begin{array}{c}0.700^{\star \star *} \\
(4.2)\end{array}$ & $\begin{array}{c}0.707^{\star \star *} \\
(4.95)\end{array}$ \\
\hline marginality & $\begin{array}{c}-0.081 \\
(1.32)\end{array}$ & $\begin{array}{c}-0.050 \\
(0.76)\end{array}$ & $\begin{array}{c}-0.042 \\
(0.67)\end{array}$ & $\begin{array}{c}-0.049 \\
(0.81)\end{array}$ & $\begin{array}{c}-0.038 \\
(0.62)\end{array}$ \\
\hline degrees rate & $\begin{array}{l}0.045 \\
(0.10)\end{array}$ & $\begin{array}{l}0.027 \\
(0.06)\end{array}$ & $\begin{array}{l}0.155 \\
(0.37)\end{array}$ & $\begin{array}{l}0.207 \\
(0.50)\end{array}$ & $\begin{array}{l}0.179 \\
(0.43)\end{array}$ \\
\hline unployment rate & $\begin{array}{l}0.147 \\
(0.30)\end{array}$ & $\begin{array}{l}0.333 \\
(0.65)\end{array}$ & $\begin{array}{l}0.435 \\
(0.88)\end{array}$ & $\begin{array}{l}0.240 \\
(0.50)\end{array}$ & $\begin{array}{l}0.241 \\
(0.48)\end{array}$ \\
\hline population density & $\begin{array}{l}0.004 \\
(0.36)\end{array}$ & $\begin{array}{l}0.007 \\
(0.66)\end{array}$ & $\begin{array}{l}0.007 \\
(0.67)\end{array}$ & $\begin{array}{c}-0.002 \\
(0.18)\end{array}$ & $\begin{array}{l}0.009 \\
(0.82)\end{array}$ \\
\hline aggregate turnout & & $\begin{array}{l}0.427 \\
(1.53)\end{array}$ & $\begin{array}{c}0.473^{\star} \\
(1.73)\end{array}$ & & $\begin{array}{l}0.384 \\
(1.45)\end{array}$ \\
\hline interest in politics & & & & & $\begin{array}{c}0.035^{\star \star *} \\
(3.65)\end{array}$ \\
\hline ideological self-placement & & & & & $\begin{array}{c}0.015^{\star \star} \\
(2.37)\end{array}$ \\
\hline party attachment & & & & & $\begin{array}{c}0.130 \text { *** } \\
(6.95)\end{array}$ \\
\hline education & $\begin{array}{l}0.009 \\
(1.64)\end{array}$ & $\begin{array}{l}0.009 \\
(1.64)\end{array}$ & {$[0.20]$} & {$[0.17]$} & {$[0.53]$} \\
\hline income & $\begin{array}{l}0.003 \\
(1.21)\end{array}$ & $\begin{array}{l}0.003 \\
(1.14)\end{array}$ & {$[0.01]^{\star \star \star}$} & {$[0.01]^{\star \star \star}$} & {$[0.01]^{\star \star \star}$} \\
\hline church attendance & $\begin{array}{c}0.009 * * \\
(2.40)\end{array}$ & $\begin{array}{c}0.009 * * \\
(2.39)\end{array}$ & {$[0.09]^{\star}$} & {$[0.02]^{\star \star}$} & {$[0.05]^{\star}$} \\
\hline Observations & 2882 & 2882 & 2882 & 2882 & 2843 \\
\hline Pseudo-R2 & 0.1297 & 0.1310 & 0.1501 & 0.0950 & 0.1657 \\
\hline Observed P & 0.7922 & 0.7922 & 0.7922 & 0.7922 & 0.7924 \\
\hline Predicted $\mathrm{P}$ (at the mean) & 0.8180 & 0.8182 & 0.8238 & 0.8132 & 0.8282 \\
\hline
\end{tabular}

The table reports marginal effects at the mean for continuos variables and the probability variation determined by a switch from 0 to 1 for dummy variables. All regressions include a constant and regional dummies.

Robust z-statistics in round brackets. * significant at 10\%; ** significant at 5\%; *** significant at $1 \%$

For categorical variables (education, income and churchgoer in columns 3-5) we report in square brackets the p-value of a Wald test and use the stars to indicate the joint significance of the coefficients. 
Tab. 3: Information and Turnout: probit estimates

\begin{tabular}{|c|c|c|c|c|}
\hline Dependent variable: Turnout & $(1)$ & $(2)$ & (3) & $(4)$ \\
\hline information & $\begin{array}{c}0.037^{\star \star \star *} \\
(6.33)\end{array}$ & $\begin{array}{c}0.029 \star \star \star \star \\
(4.71)\end{array}$ & $\begin{array}{c}0.114^{\star} \\
(1.88)\end{array}$ & $\begin{array}{l}0.116^{*} \\
(1.95)\end{array}$ \\
\hline age & $\begin{array}{c}-0.005 \\
(1.54)\end{array}$ & $\begin{array}{c}-0.003 \\
(0.98)\end{array}$ & $\begin{array}{c}-0.013^{\star *} \\
(1.96)\end{array}$ & $\begin{array}{c}-0.011^{*} \\
(1.92)\end{array}$ \\
\hline age2 & $\begin{array}{l}0.005 \\
(1.47)\end{array}$ & $\begin{array}{l}0.002 \\
(0.73)\end{array}$ & $\begin{array}{c}0.011^{\star *} \\
(1.99)\end{array}$ & $\begin{array}{l}0.009^{*} \\
(1.78)\end{array}$ \\
\hline married & $\begin{array}{c}0.044^{* *} \\
(2.12)\end{array}$ & $\begin{array}{c}0.041^{* *} \\
(2.04)\end{array}$ & $\begin{array}{c}0.043^{\star \star} \\
(2.10)\end{array}$ & $\begin{array}{l}0.038^{*} \\
(1.87)\end{array}$ \\
\hline gender & $\begin{array}{c}-0.044^{\star \star} \\
(2.24)\end{array}$ & $\begin{array}{c}-0.036^{*} \\
(1.86)\end{array}$ & $\begin{array}{c}-0.088^{\star *} \\
(2.25)\end{array}$ & $\begin{array}{c}-0.076^{\star \star} \\
(2.42)\end{array}$ \\
\hline asian & $\begin{array}{c}0.088^{*} \\
(1.65)\end{array}$ & $\begin{array}{l}0.054 \\
(0.94)\end{array}$ & $\begin{array}{c}0.124^{\star \star} \\
(2.14)\end{array}$ & $\begin{array}{c}0.100^{\star} \\
(1.71)\end{array}$ \\
\hline black & $\begin{array}{c}-0.029 \\
(0.28)\end{array}$ & $\begin{array}{c}-0.126 \\
(0.94)\end{array}$ & $\begin{array}{c}-0.033 \\
(0.31)\end{array}$ & $\begin{array}{c}-0.138 \\
(1.00)\end{array}$ \\
\hline union member & $\begin{array}{l}0.005 \\
(0.26)\end{array}$ & $\begin{array}{l}0.004 \\
(0.22)\end{array}$ & $\begin{array}{c}-0.014 \\
(0.61)\end{array}$ & $\begin{array}{c}-0.014 \\
(0.68)\end{array}$ \\
\hline length of residence & $\begin{array}{l}0.001 \\
(1.44)\end{array}$ & $\begin{array}{l}0.001 \\
(1.27)\end{array}$ & $\begin{array}{l}0.000 \\
(0.39)\end{array}$ & $\begin{array}{c}-0.000 \\
(0.10)\end{array}$ \\
\hline full time job & $\begin{array}{c}-0.028 \\
(1.24)\end{array}$ & $\begin{array}{c}-0.030 \\
(1.37)\end{array}$ & $\begin{array}{c}-0.012 \\
(0.49)\end{array}$ & $\begin{array}{c}-0.011 \\
(0.44)\end{array}$ \\
\hline house owner & $\begin{array}{l}0.026 \\
(1.17)\end{array}$ & $\begin{array}{l}0.038^{*} \\
(1.72)\end{array}$ & $\begin{array}{l}0.011 \\
(0.42)\end{array}$ & $\begin{array}{l}0.021 \\
(0.84)\end{array}$ \\
\hline quality newspaper reader & $\begin{array}{l}0.020 \\
(0.66)\end{array}$ & $\begin{array}{l}-0.005 \\
(0.15)\end{array}$ & $\begin{array}{c}-0.036 \\
(0.64)\end{array}$ & $\begin{array}{c}-0.042 \\
(1.03)\end{array}$ \\
\hline canvasser & $\begin{array}{c}0.060 * \star * \\
(3.13)\end{array}$ & $\begin{array}{c}0.054^{\star \star \star} \\
(2.81)\end{array}$ & $\begin{array}{c}0.045^{\star \star} \\
(2.00)\end{array}$ & $\begin{array}{c}0.038^{*} \\
(1.72)\end{array}$ \\
\hline voted in 1992 & $\begin{array}{c}0.251^{* * *} \\
(9.58)\end{array}$ & $\begin{array}{c}0.200^{\star \star * *} \\
(7.82)\end{array}$ & $\begin{array}{c}0.200^{\star * *} \\
(4.99)\end{array}$ & $\begin{array}{c}0.168^{\star \star *} \\
(5.89)\end{array}$ \\
\hline aware of being registered & $\begin{array}{c}0.718^{\star \star \star \star} \\
(4.17)\end{array}$ & $\begin{array}{c}0.710^{\star \star \star *} \\
(4.64)\end{array}$ & $\begin{array}{c}0.709 * \star \star \\
(4.06)\end{array}$ & $\begin{array}{c}0.706^{\star \star \star} \\
(4.59)\end{array}$ \\
\hline marginality & $\begin{array}{c}-0.006 \\
(0.09)\end{array}$ & $\begin{array}{r}-0.007 \\
(0.12)\end{array}$ & $\begin{array}{l}0.064 \\
(0.79)\end{array}$ & $\begin{array}{l}0.074 \\
(0.93)\end{array}$ \\
\hline degrees & $\begin{array}{l}0.058 \\
(0.14)\end{array}$ & $\begin{array}{l}0.121 \\
(0.29)\end{array}$ & $\begin{array}{c}-0.027 \\
(0.06)\end{array}$ & $\begin{array}{l}0.080 \\
(0.19)\end{array}$ \\
\hline unemployment rate & $\begin{array}{l}0.185 \\
(0.37)\end{array}$ & $\begin{array}{l}0.084 \\
(0.16)\end{array}$ & $\begin{array}{l}-0.225 \\
(0.39)\end{array}$ & $\begin{array}{l}-0.239 \\
(0.44)\end{array}$ \\
\hline population density & $\begin{array}{l}0.011 \\
(1.04)\end{array}$ & $\begin{array}{l}0.011 \\
(1.07)\end{array}$ & $\begin{array}{l}0.017 \\
(1.48)\end{array}$ & $\begin{array}{l}0.016 \\
(1.45)\end{array}$ \\
\hline aggregate turnout & $\begin{array}{l}0.428 \\
(1.58)\end{array}$ & $\begin{array}{l}0.360 \\
(1.37)\end{array}$ & $\begin{array}{l}0.323 \\
(1.15)\end{array}$ & $\begin{array}{l}0.262 \\
(0.97)\end{array}$ \\
\hline political interest & & $\begin{array}{c}0.022^{\star *} \\
(2.26)\end{array}$ & & $\begin{array}{c}-0.016 \\
(0.62)\end{array}$ \\
\hline ideological self_placement & & $\begin{array}{c}0.010^{\star} \\
(1.70)\end{array}$ & & $\begin{array}{l}0.000 \\
(0.03)\end{array}$ \\
\hline party attachment & & 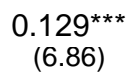 & & $\begin{array}{c}0.138^{\star \star \star} \\
(6.83)\end{array}$ \\
\hline first stage residuals & & & $\begin{array}{c}-0.078 \\
(1.28)\end{array}$ & $\begin{array}{c}-0.088 \\
(1.30)\end{array}$ \\
\hline education & {$[0.60]$} & [0.63] & {$[0.53]$} & {$[0.47]$} \\
\hline income & {$[0.01]^{\star \star \star}$} & {$[0.01]^{\star \star \star}$} & {$[0.01]^{\star \star \star}$} & {$[0.01]^{\star \star \star}$} \\
\hline church attendance & [0.12] & [0.08] & {$[0.24]$} & {$[0.14]$} \\
\hline $\begin{array}{l}\text { Observations } \\
\text { Pseudo-R2 } \\
\text { Observed P } \\
\text { Predicted P (at the mean) }\end{array}$ & $\begin{array}{l}2882 \\
0.1688 \\
0.7922 \\
0.8288\end{array}$ & $\begin{array}{l}2843 \\
0.1765 \\
0.7924 \\
0.8309\end{array}$ & $\begin{array}{c}2882 \\
0.1696 \\
0.7922 \\
0.8289\end{array}$ & $\begin{array}{l}2843 \\
0.2002 \\
0.7924 \\
0.8386 \\
\end{array}$ \\
\hline
\end{tabular}

The table reports marginal effects at the mean for continuos variables and the probability variation determined by a switch from 0 to 1 for dummy variables. All regressions include a constant and regional dummies.

Robust z-statistics in round brackets. Standard errors for information and residuals in columns 3 and 4 have

been calculated by boostrap. * significant at $10 \%$; ** significant at $5 \%$; *** significant at $1 \%$.

For categorical variables (education, income and churchgoer) we report in square brackets the p-value of a Wald test and use stars to indicate the joint significance of the coefficients. 
Fig.2: Predicted voting probability as a function of information

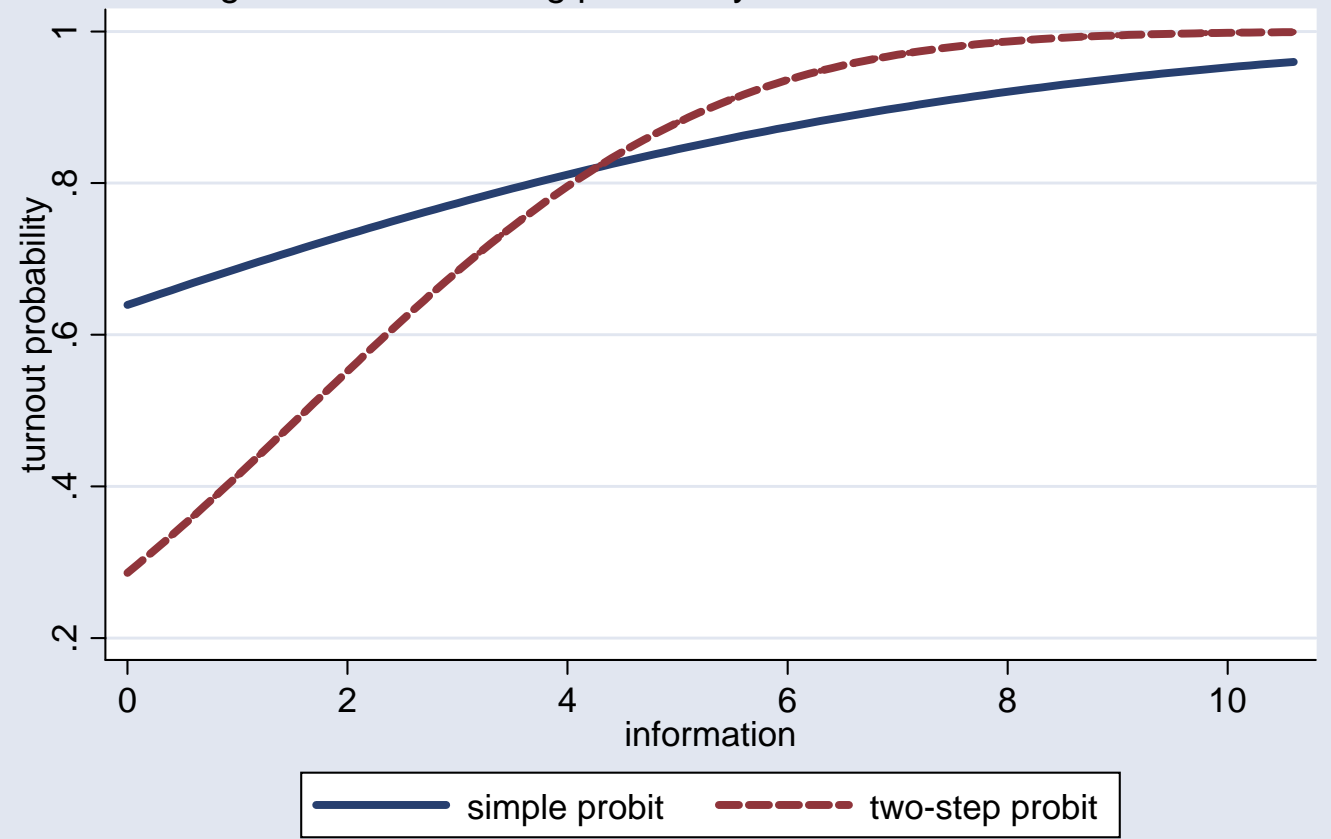

Other variables are kept constant at their mean values. Political disposition variables are not included 


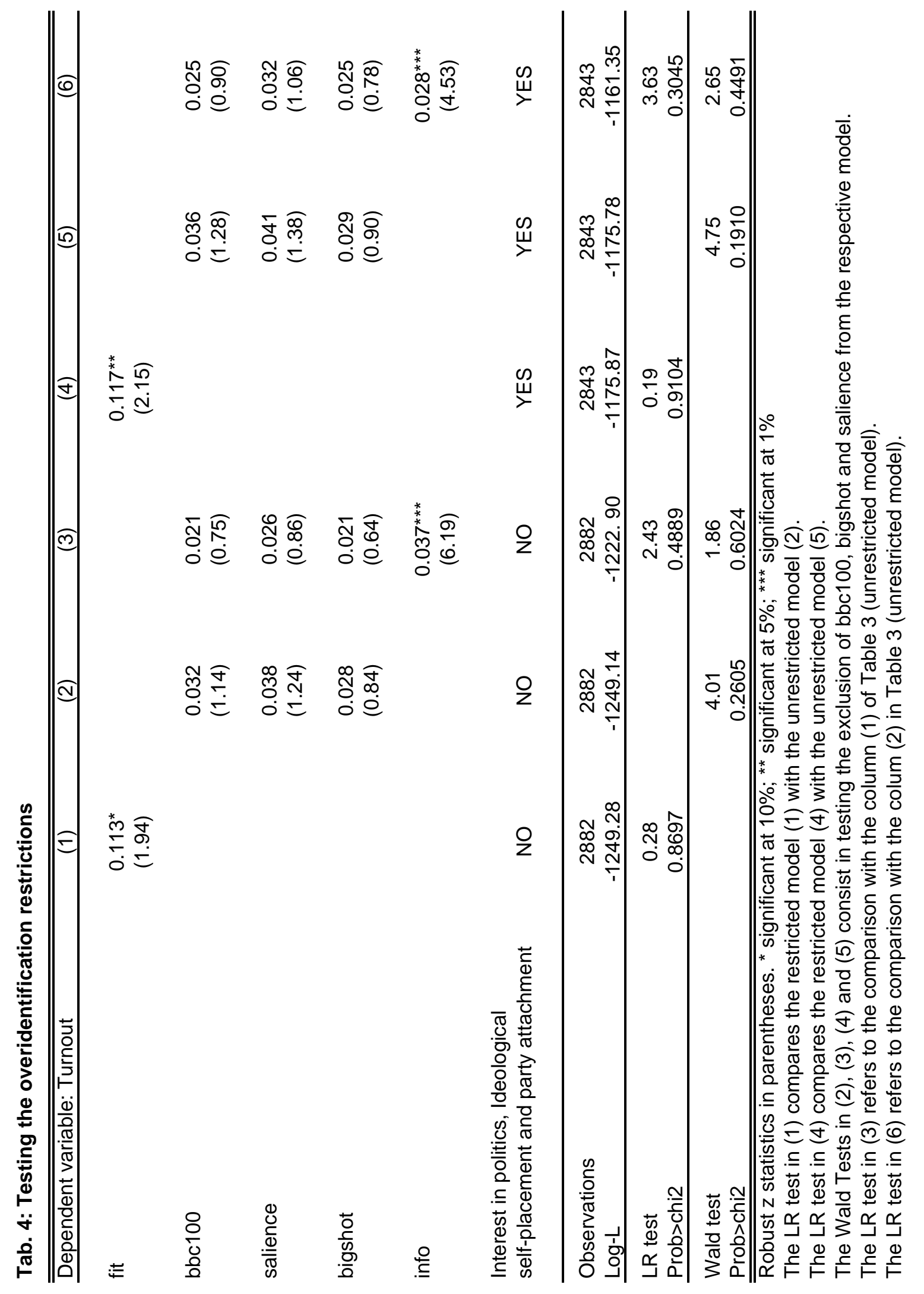


Tab. 5: First stage regressions

\begin{tabular}{|c|c|c|}
\hline Dependent variable: information & $(1)$ & $(2)$ \\
\hline bbc100 & $\begin{array}{c}0.351^{\star \star \star} \\
(3.33)\end{array}$ & $\begin{array}{c}0.372^{\star \star *} \\
(3.67)\end{array}$ \\
\hline bigshot & $\begin{array}{l}0.307^{\star *} \\
(2.31)\end{array}$ & $\begin{array}{c}0.294^{* *} \\
(2.31)\end{array}$ \\
\hline media salience & $\begin{array}{l}0.229^{\star *} \\
(1.97)\end{array}$ & $\begin{array}{c}0.284^{\star \star \star} \\
(2.64)\end{array}$ \\
\hline age & $\begin{array}{c}0.098^{\star \star \star *} \\
(7.52)\end{array}$ & $\begin{array}{c}0.091^{\star \star \star} \\
(7.39)\end{array}$ \\
\hline age2 & $\begin{array}{c}-0.080^{\star * *} \\
(6.09)\end{array}$ & $\begin{array}{c}-0.077^{\star \star \star} \\
(6.25)\end{array}$ \\
\hline married & $\begin{array}{l}0.006 \\
(0.08)\end{array}$ & $\begin{array}{l}0.034 \\
(0.44)\end{array}$ \\
\hline gender & $\begin{array}{c}0.591^{* \star *} \\
(8.08)\end{array}$ & $\begin{array}{c}0.471^{\star \star \star} \\
(6.76)\end{array}$ \\
\hline asian & $\begin{array}{c}-0.826^{\star \star *} \\
(4.03)\end{array}$ & $\begin{array}{c}-0.782^{\star \star \star} \\
(4.23)\end{array}$ \\
\hline black & $\begin{array}{l}0.063 \\
(0.20)\end{array}$ & $\begin{array}{l}0.113 \\
(0.44)\end{array}$ \\
\hline union member & $\begin{array}{c}0.253^{\star \star \star *} \\
(3.60)\end{array}$ & $\begin{array}{c}0.220^{\star \star \star} \\
(3.28)\end{array}$ \\
\hline length of residence & $\begin{array}{c}0.007^{\star \star * *} \\
(3.27)\end{array}$ & $\begin{array}{c}0.009 * * * \\
(4.43)\end{array}$ \\
\hline full time job & $\begin{array}{c}-0.202^{\star *} \\
(2.44)\end{array}$ & $\begin{array}{c}-0.223^{\star \star \star} \\
(2.87)\end{array}$ \\
\hline house owner & $\begin{array}{l}0.199^{\star *} \\
(2.38)\end{array}$ & $\begin{array}{l}0.192^{\star *} \\
(2.40)\end{array}$ \\
\hline quality newspaper reader & $\begin{array}{c}0.737^{\star * * *} \\
(7.23)\end{array}$ & $\begin{array}{c}0.422^{\star \star \star} \\
(4.27)\end{array}$ \\
\hline canvasser & $\begin{array}{l}0.175^{\star *} \\
(2.29)\end{array}$ & $\begin{array}{c}0.163^{\star *} \\
(2.23)\end{array}$ \\
\hline voted in 1992 & $\begin{array}{c}0.483^{\star * *} \\
(5.24)\end{array}$ & $\begin{array}{c}0.264^{\star \star \star} \\
(2.95)\end{array}$ \\
\hline aware of being registered & $\begin{array}{l}0.254 \\
(0.64)\end{array}$ & $\begin{array}{l}0.155 \\
(0.34)\end{array}$ \\
\hline marginality & $\begin{array}{c}-0.777^{\star * *} \\
(3.27)\end{array}$ & $\begin{array}{c}-0.773^{* * *} \\
(3.41)\end{array}$ \\
\hline degrees & $\begin{array}{l}0.811 \\
(0.50)\end{array}$ & $\begin{array}{l}0.113 \\
(0.07)\end{array}$ \\
\hline unemployment rate & $\begin{array}{c}4.993^{\star \star *} \\
(2.62)\end{array}$ & $\begin{array}{l}3.382^{*} \\
(1.87)\end{array}$ \\
\hline population density & $\begin{array}{c}-0.079^{*} \\
(1.90)\end{array}$ & $\begin{array}{l}-0.058 \\
(1.44)\end{array}$ \\
\hline aggregate turnout & $\begin{array}{l}0.687 \\
(0.70)\end{array}$ & $\begin{array}{l}0.402 \\
(0.45)\end{array}$ \\
\hline political interest & & $\begin{array}{c}0.448^{\star \star \star} \\
(13.50)\end{array}$ \\
\hline ideological self_placement & & $\begin{array}{c}0.118^{\star \star \star} \\
(5.16)\end{array}$ \\
\hline party attachment & & $\begin{array}{c}-0.120^{\star} \\
(1.69)\end{array}$ \\
\hline education & {$[0.00]^{\star \star \star}$} & {$[0.00]^{\star * *}$} \\
\hline income & {$[0.12]$} & {$[0.12]$} \\
\hline church attendance & [0.39] & {$[0.31]$} \\
\hline $\begin{array}{l}\text { Observations } \\
\text { R-squared }\end{array}$ & $\begin{array}{c}2882 \\
0.3224\end{array}$ & $\begin{array}{c}2843 \\
0.3886\end{array}$ \\
\hline
\end{tabular}


Table A1: Summary statistics

\begin{tabular}{|c|c|c|c|c|c|}
\hline Variable & Obs & Mean & Std. Dev. & Min & Max \\
\hline turnout & 2882 & .7876475 & .409044 & 0 & 1 \\
\hline information & 2882 & 4.26118 & 1.833865 & 0 & 10.62 \\
\hline bbc100 & 2882 & .129771 & .3361096 & 0 & 1 \\
\hline salience & 2882 & .1065232 & .3085597 & 0 & 1 \\
\hline bigshot & 2882 & .0725191 & .2593905 & 0 & 1 \\
\hline age & 2882 & 48.61659 & 17.65495 & 18 & 95 \\
\hline edu & 2882 & 3.569396 & 2.16618 & 1 & 7 \\
\hline income & 2882 & 6.989591 & 4.581465 & 1 & 16 \\
\hline married & 2882 & .5860514 & .492625 & 0 & 1 \\
\hline gender & 2882 & .4656489 & .4989052 & 0 & 1 \\
\hline asian & 2882 & .01839 & .1343804 & 0 & 1 \\
\hline black & 2882 & .0090215 & .0945686 & 0 & 1 \\
\hline church attendance & 2882 & 1.975364 & 2.601047 & 0 & 7 \\
\hline union member & 2882 & .593338 & .491296 & 0 & 1 \\
\hline length of residence & 2882 & 19.75989 & 18.0382 & 0 & 94 \\
\hline full time job & 2882 & .7581541 & .4282758 & 0 & 1 \\
\hline house owner & 2882 & .6776544 & .4674556 & 0 & 1 \\
\hline retired & 2882 & .2338654 & .423361 & 0 & 1 \\
\hline quality newspaper reader & 2882 & .1186676 & .3234531 & 0 & 1 \\
\hline canvasser & 2882 & .2890354 & .4533931 & 0 & 1 \\
\hline voted in 1992 & 2882 & .7987509 & .4010034 & 0 & 1 \\
\hline aware of registration & 2882 & .9944483 & .0743155 & 0 & 1 \\
\hline party attachment & 2882 & .2366412 & .4250939 & 0 & 1 \\
\hline interest in politics & 2882 & 3.029146 & 1.053177 & 1 & 5 \\
\hline ideological strenght & 2843 & 1.202603 & 1.524986 & 0 & 5 \\
\hline marginality & 2882 & .3032604 & .1936666 & .0051282 & .8140044 \\
\hline aggregate turnout & 2882 & .7130278 & .0511328 & .514 & .8 \\
\hline degrees & 2882 & .0603349 & .0269313 & .0149414 & .1797613 \\
\hline unemployment & 2882 & .0929566 & .0395296 & .0286795 & .2248957 \\
\hline population density & 2882 & 1.344676 & 1.669413 & .0021854 & 11.10492 \\
\hline
\end{tabular}

